\title{
Development And Validation Of A Technology Ability Test (TAT) For Admission Of Students Into Technology Teacher Education Programmes In Nigerian Universities
}

\author{
Dr Emmanuel E. Inyiagu \\ Technology and vocational education department, \\ Ebonyi State University, Abakaliki, Ebonyi State, Nigeria
}

doi: 10.19044/esj.2016.v12n1p444 URL:http://dx.doi.org/10.19044/esj.2016.v12n1p444

\begin{abstract}
This study was an instrumentation research. The purpose of the study was to develop and validate a Technology Ability Test (TAT) for admission of students into Technology Teacher Education Programmes in Nigerian Universities. A sample of 120 students drawn from four universities in the southeast geopolitical zone of Nigeria that offers the programme was used for the study. Six research questions were answered and two hypotheses tested in the study. The 50 - items TAT that emerged after the preliminary testing was used for data collection. Results of TAT's psychometric qualities indicated that 80 percent of the items possessed moderate difficulty and high (suitable) discrimination indices. The reliability coefficient obtained from the test is 0.96 , which indicates that TAT is very reliable. Results further revealed that gender has slight influence on the Technology Ability Test, students of the federal universities performed marginaly better than their state counterparts and that TAT scores has very low concurrent validity with JAMB scores. The educational implications of the findings when the developed Technology Ability Test (TAT) is adopted included helping admission officers and counselors to objectively identify students with the capability to succeed in technology teacher education programmes in Nigerian Universities and data obtained after the administration will provide efficient indices for future performances of students in technology teacher education, since a valid ability test is also predictive. Based on the findings of this study, the researcher recommended that the developed test be used in admiting candidates into technology teacher education programmes and admission officers be trained on how to use the newly developed test.
\end{abstract}

Keywords: Instrumentation research, Technology ability test, Technology teacher education, Validity, Reliability 


\section{Introduction}

Technology teacher education programme, which leads to the production of technology teachers, is offered in Universities, some Polytechnics and some Colleges of Education in Nigeria. A technology teacher is a professional in his chosen occupation, who possesses competent skills that enable him teach effectively. The technology teacher also emphasizes practical activities in the curriculum within the framework of technology techer education, which leads to the mastery of functional technical knowledge being imparted to the students. Umeh (2002) observed that technology determines the world politics, economics and influences management techniques and objectives. Technology teachers according to him are also expected to be well equipped technologically to enable them impart saleable skills to students. According to Olaitan (2006), the major objectives of technology teacher education programmes in Nigeria are to meet the work force needs of the nation's secondary, technical and technological institutions, to assist in increasing the occupational options available to youths after graduation and to help motivate the students in skill learning for occupations through the technology teachers.

Obi (2005) identified Mechanical, Electrical/Electronics, Building/Woodwork and Computer Technology as the areas of specialization in technology education. The primary mode of admission of students into the various technology education programmes in Nigerian Universities is by the University Matriculation Examination (UME), organized by the Joint Admission and Matriculation Board (JAMB). Okoro (2006) stated that the Board was established in Nigeria in the year 1976 with the aim of stopping irregularities in West African Examination Council (WAEC) Examination, multiple admissions by the decentralized admission policy and comparability of standards across Universities.

Agwagwa and Agbaegbu (2007) also stated that the Board was established to streamline, and co-ordinate university admission in Nigeria. The functions of JAMB are well specified in the 1976 Act establishing it and in the Decree no 36 of 1989. The first examination of the Board, which was conducted in May 1978, was with minimal hitches. Nwana (2001) stated that in present time, JAMB examinations have become about the most turbulent examination in Nigeria. One needs to observe the environmental concomitants during JAMB examination in some areas, such as high rate of infiltration on school compound including swift vehicular movements through which malpractice is aided and abated. Some staff quarters are converted to mini clearing houses for bridging examination gaps (Umo, 2006). Some of them are used as organs of dissemination of worked answers. In this milieu, the school environment that is supposed to be characterized by calmness is infested with noise, rowdiness, disturbance and misdemeanor. 
Nwafor and Onuoha (2014) identified many factors that cause examination malpractices in Nigeria. These include psychological stress, fear of failure, insufficient preparation, general high level of corruption in the society, teachers lack of motivation and devotion, among others. The implication of this malpractice is the unreliable UME scores obtained. Meaning that candidates who are not qualified to gain admission, find themselves in the four walls of higher institutions (Ezeudu and Umoh, 2007). The effect of this unreliable UME scores on the undergraduates can never be over-emphasized. This, according to Ayo (2012), is among the causes of cultism in the Universities. Therefore, the Universities are supplied with many students that never passed their entrance examinations by merit. Lecturers are threatened, assaulted and intimidated by these students who must find a way of passing examinations through foul means.

According to Ayo (2012), these malpractices have resulted in a general fall in the standard of university education in Nigeria. Consequently, the Federal Ministry of Education in 2005 introduced the policy of post-JAMB screening by Universities. This policy made it mandatory for all tertiary institutions in Nigeria, to undertake the task of further screening candidates after their JAMB results, before giving them admission. The first post-JAMB Screening examinations results revealed cases of candidates who had 280 and above in JAMB, but could not score 20 percent in the post-JAMB examinations. According to the Minister, these persons must have engaged in cheating during JAMB examinations and so could not pass the post-JAMB examination because there was no room to cheat or impersonate.

However, it appears that, UME is more prone to malpractice as the invigilators are heterogeneous, while those of the university screening are responsible academics made up of groups who are challenged to protect their integrity and profession as invigilators. In addition, the screening environment is friendlier to examination ethics with halls and seats well arranged and well spaced. The common element according to Ezeudu and Umoh (2007) in both examinations is the questions, which are pulled from the same item bank. This means that universities use the same screening test for students seeking admission into the faculties of engineering, sciences as well as technology education.

Ohize (2007) pointed out that this practice of using the same post-JAMB screening test items to admit students into engineering, science and technology education programmes is not appropriate, because students' ability, interest and value are not considered. The effect of this practice, according to Ohize and, Imah and Nneji (2006) is the admission of illprepared students, who do not have the special ability and desire to enter and succeed in a technology education programme. Upon this background, a dependable instrument called Technology Ability Test (TAT) is required as a 
separate screening test for admission of technology education students. Abonyi (2003), defined ability test as test designed to assess competence in an activity or occupation, based on one's skills, capacity, means or other special qualifications. It is generally used as measures of a cognitive behaviour. He further stated that, ability test is a combination of achievement and aptitude test items. Technology ability test is therefore, a set of test on various technology options designed to determine both natural and acquired potentials of an individual to succeed in a particular technology teacher education.

Previous studies in technology skill acquisition revealed gender sensitivity in achievement and interest (Ugwu, 2006 \& Modili, 2005). Udigwe (2000) presented an argument that technology skills and operations are masculine and involves more energy exertion, therefore tends to favour males more than females. This argument was however refuted by Yaduma (2006), who observed that achievement in technology skills is mostly influenced by interest, rather than personality attributes of being male or female.

However, Uzoagulu (1994) discovered that the male students tended to perform better than their female counterparts in all the content areas of his study, but they exhibited greater homogeneity than the male counterparts in terms of measures of dispersion of scores from the mean scores. There is yet no available instrument specifically on technology teacher education and it has also not been estimated the extent to which such instrument would respond to gender.

\section{Statement of the Problem}

In the recent past, there have been many criticisms on the conduct of University Matriculation Examination (UME). The examination is seen as unreliable (Ezeudu and Umoh, 2007). Apart from the high level of malpractice associated with the examination, there was also categorization of centers as special or ordinary, depending on the amount of money the candidate can offer. This unreliable nature of JAMB scores, coupled with the fact that some candidates who scored highly in UME could not defend such scores on admission, some universities in Nigeria introduced post-JAMB screening exercises, which was ab-initio recognized and supported by Mrs Chinwe Obaji, former Minister for Education in Nigeria.

With the introduction of this post JAMB screening, it was believed that the problems of admitting wrong candidates into universities had been solved. However, Ohize (2007) pointed out that the practice of using the same post JAMB screening items to admit science, engineering and technology education students is improper, because student's ability, interest and value, rather than success in JAMB ought to be considered. The result of 
this practice according to Imah and Nneji (2006) is the admission of candidates who do not have the special ability or desire to enter and succeed in a technology education programme. Udenze (2006) observed that students who register for technology education programmes sometimes do not complete the programme. They drop out or are asked to withdraw from the programme because of their inability to stand the demands of the programme. Ohize (2007) and Akinyemi (2007) blamed this ugly situation on the use of the same post-JAMB/screening test items to admit students for technology education programme and students of other faculties in the university. This wrong practice is one of the factors impeding effective guidance and counselling in Nigeria (Ikeotuonye, 2011).

Since admission of students into technology education programmes is synonymous with choosing an occupation, Salami (2007) advised that it is crucial to test the students' level of acquisition of preliminary knowledge, skill and awareness in technology reasoning that could serve as a springboard for choosing technology education programmes. It therefore, becomes imperative to ask whether the country should continue to spend money in training uninterested students, when this could have been dictated using a valid and reliable ability test. There is therefore, the need to develop a separate screening test items for admission of technology education students.

The problem of this study posed as a question is can a set of validated Technology Ability Test be developed, which can be used to assess prospective students' capability to do well and succeed in a technology teacher education programme?

\section{Purpose of the Study}

This study developed and validated a Technology Ability Test. The test was used to identify students suitable for admission into technology education programmes in South Eastern Zone of Nigeria. Specifically, the study:

1. Ascertained the validity of the Technology Ability Test.

2. Established the reliability of the Technology Ability Test.

3. Determined the influence of gender on the performances of students in different subsets of the Technology Ability Test.

4. Determined the influence of university ownership on the performances of students in different subsets of the Technology Ability Test. 5. Determined the concurrent validity between JAMB scores and the TAT scores.

\section{Significance of the Study}


The benefits that shall accrue from this study are many. When the developed TAT is utilised, it will help admission officers and counselors to objectively identify students with the capability to succeed in technology courses in Nigerian Universities. Such objective selection of students will minimize the financial loss the country incurs because of admitting unqualified candidates into technology education programmes.

The study will also enhance educational practice, since the measures obtained using the instrument will truly and adequately reflect the learners' understanding of basic technology taught at the secondary school. The data provided from administering the test, will provide efficient proof for future performances of students in technology courses, which formed major content in the technology programme, since a valid ability test is also predictive (Uzoagulu, 1994).

Sstudents' performance on the instrument will guide university teachers and guidance counselors to objectively guide admitted students to take wise decisions regarding their choices from the various technology sections/options available. These include; Mechanical, Building/Woodwork and Electrical/Electronics Technology.

The society will invariably benefit from this study when students are assisted to choose right career that will afford them better skills to serve the society effectively. All these will be achieved, when various universities use the Technology Ability Test to ensure dependable assessment of students' ability, thereby indicating to government whether the objectives for introducing basic technology into the curriculum of Nigerian schools has been achieved.

Recent attempts by test developers in Nigeria are the development of item banks for various purposes and subject areas. These are files of various suitable test items that are coded by subject areas, instructional levels, instructional objectives and various pertinent item characteristics like item difficulty and discrimination powers. The development and validation of the Technology Ability Test can boost item banking for general educational purposes in Nigeria.

Finally, the educational significance of this study is that the quality of technology education in the country will improve when capable students are admited because the individual students will be at their best during their study periods in the universities, since their estimated abilities suit the demands of their chosen course.

\section{Scope of the Study}

Specifically, the study is concerned with the development of and validation of an ability test that could be used to measure students' special ability to do well in technology education programmes in Nigerian 
universities. The scope of the Technology Ability Test (TAT) was restricted to five areas: Mechanical, Building/Woodwork and Electrical/Electronics Technology. Other areas include Graphic Language (Technical Drawing) and Safety Consciousness. The study could not cover the entire aspects of technology education. Programmes like computer technology and ceramics technology were not covered, because they are not very common options in the programme.

\section{Research Questions}

The following research questions guided the study:

1. What is the validity of the Technology Ability Test?

2. What is the reliability of the Technology Ability Test?

3. What is the influence of gender on the performances of students in different subsets of the Technology Ability Test?

4. What is the influence of university ownership on the performances of students in different subsets of the Technology Ability Test?

5. What is the concurrent validity between JAMB scores and the TAT scores?

\section{Research Hypotheses}

The following hypotheses were tested at 0.05 level of significance:

Ho1: There is no significant difference in the mean achievement scores of federal and state universities on the Technology Ability Test (TAT).

Ho2: There is no gender influence on the mean achievement scores of the students of both federal and state universities on the Technology Ability Test (TAT).

\section{Methodology}

This study is an instrumentation study. According to Garba (2003), instrumentation studies are appropriate when developing instruments for educational practice. In this study, a new set of validated and reliable test called Technology Ability Test (TAT) for admission of students into technology teacher education programmes in Nigerian Universities was developed.

\section{Area of the Study}

The study was carried out in the South East Geopolitical Zone of Nigeria. Preliminary data gathered from the 2006/2007 JAMB brochure revealed that only four universities in the Zone are offering technology teacher education. These universities are University of Nigeria, Nsukka; Ebonyi State University, Abakaliki; Enugu State University of Science and 
Technology, Enugu and Nnamdi Azikiwe University, Awka. The use of this area for this study was guided by the fact that they have the nearest universities to the researcher that is offering technology teacher education.

\section{Population of the Study}

The population for this study consisted of all the current first year technology students of the department of technology and vocational education of the universities offering technology education programmes in the southeast geopolitical zone of Nigeria. Joint Admission and Matriculation Board (JAMB) Brochure (2010) revealed that only four universities in the zone are offering Technology Education. These are; University of Nigeria, Nsukka (UNN), Ebonyi State University (EBSU), Abakaliki; Enugu State University of Science and Technology (ESUT), Enugu, and Nnamdi Azikiwe University, (NAU), Awka. University of Nigeria, Nsukka and Nnamdi Azikiwe University, Awka are federal universities, while Ebonyi State University, Abakaliki and Enugu State University of Science and Technology, Enugu are state owned universities. The first year students of these four universities constituted the population of the study.

The choice of first year undergraduates of technology teacher education department is guided by the fact that they are close equivalent to the intending undergraduates for whom the technology ability test is meant. In addition, the difficulty that the researcher would encounter in trying to assemble intending candidates for admissions in the various universities at the same time, was considered. The data gathered by the researcher on the preliminary visit to the various technology departments showed that the departments have an estimated first year technology students population of 186 (one hundred and eighty six students, see Table 1).

\section{Sample and Sampling Technique}

Sampling, as a statistical means, refers to the strategy adopted by investigators in order to arrive at a good representation of the population (Uzoagulu, 1998:66). Thirty students were selected through a random sampling technique from each of the four universities offering technology education, making 120 students (see appendix A1).

\begin{tabular}{cccc}
\multicolumn{4}{c}{ Table 1: Population / Sample Distribution of the First Year Technology Students } \\
\hline S/N & Name of University & Population & Sample \\
\cline { 2 - 4 } 1. & Ebonyi State University & 34 & 30 \\
2. & Univesity of Nigeria & 57 & 30 \\
3. & Enugu State University of Science \& & 53 & 30 \\
4. & Technology & 42 & 30 \\
\cline { 2 - 4 } & Nnamdi Azukwe University & 186 & 120 \\
\hline
\end{tabular}




\section{Instrument for Data collection}

Data for this study was collected with the aid of the Technology Ability Test, developed by the researcher. It is a 50-item multi-choice type test which covered five technology areas; Mechanical, Building/Woodwork, Electrical/Electronics, Graphic Language (Technical Drawing) and Safety Consciousness. Each of the 5 technology areas consisted of 10 - items giving a total of 50 - items Technology Ability Test (TAT).

Validity and Reliability Analysis of the Final Test (Nworgu, 2002)

The above outlined plan by Nworgu (2002) was followed by the researcher for developing the TAT. In generating the first draft copy of the technology ability test, the researcher considered the junior secondary basic technology curriculum of the Federal Ministry of Education and built a test blueprint which guided item generation. The six levels cognitive domain of the Bloom's taxonomy were considered in designing the Table of Specifications. Based on content areas of basic technology, 48 items were developed covering sub-sets; 1, 2, 3 and 4 content areas. Sub-set 5 of safety consciousness was developed from general workshop safety. Each of the technology areas consisted of 12 items. In all, a set of 60 - items draft Technology Ability Test items was developed.

\section{Validation of the Instrument}

The 60 - items TAT were sent to 15 validators to validate, considering relevance and structures. Anene and Ndubisi (2002) wrote that the usual procedure for establishing the content validity of an instrument is to subject the instrument to the scrutiny of relevant experts. The relevant experts here refers to 15 technology teachers. The TAT items were however, modified in line with the recommendations of the various experts.

After the modifications by the experts that face validated the test, the instrument was administered to a sample of 30 first year technology students of technology and vocational education department of University of Uyo, which does not form part of the study. These students' papers were scored and the scores on the test were subjected to innternal validation (item analysis). Out of the 60 items that were subjected to preliminary validation exercise, 10 items were dropped, 2 items each from each of the subsets. Those dropped items were found to discriminate negatively, too difficult or appeard to be too easy. Therefore, 50 - items representing (83 per cent) of the 60 - items possessed adequate psychometric quality. The results proved the fact that the opinions of the experts who validated the technology ability test were adequately utilized. Therefore the instrument was considered valid to be used for data collection. 


\section{Reliability of the Instrument}

The second phase of the preliminary test is the establishment of the reliability coefficient of the 50 items that survived the item analysis exercice. The scores obtained were used to assess the Kuder Richardson (K-R-20) estimate of reliability for TAT. The TAT subsets had the following reliability indices: $\mathrm{Ar}=0.81, \mathrm{Br}=0.92, \mathrm{Cr}=0.82, \mathrm{Dr}=0.90, \mathrm{Er}=0.88$. The entire TAT yielded a reliability coefficient of 0.87 , indicating high reliability. The implication of these values is that TAT was properly developed and is a reliable instrument.

\section{Method of Data Collection}

The 50-item of Technology Ability Test that emerged after the preliminary testing was used for data collection. Copies of the 50-item Technology Ability Test were administered personally to the 120-year one students in the four universities. The students were required to indicate their gender, state their JAMB score and answer all the questions in the five content areas in one hour. During the administration of the instrument, the researcher ensured that all necessary clarifications were made to the students to avoid unnecessary errors in interpreting and responding to the question items. The papers were collected immediatly after for marking and scoring. The scores from the instrument formed the data that were used to answer the research questions.

\section{Method of Data Analysis}

Research question 1 was answered using item analysis procedures. The Kuder Richardson (K-R 20) approach was used to answer research question 2, while mean and standard deviation were computed to provide answer to research questions 3 and 4 . Pearson product moment correlation coefficient was used to answer research question 5. The Null Hypothesis 1 was tested using Analysis of Variance (ANOVA) at alpha level of 0.05, while the Null Hypothesis 2 was tested using t-test of difference between means of samples.

\section{Decision Rule.}

Any level of difficulty of $0.30-0.70$ is ideal for an instrument. Whereas, an ideal item in an instrument, is one that has a discrimination index ranging from $0.30-1.00$ (Nworgu, 2002). On reliability, Uzoagulu (2011) recommended that the reliability of a test instrument should not be less than 0.70. Finally, in answering research questions 3 and 4, a 50 percent mean difference was considered a significant influence of any of the variables. 


\section{Result and findings}

The results of the analysis are presented in order of the research questions and hypotheses.

Ability Test?

Research Question 1: What is the validity of the Technology

Table 2: Distribution of the Difficulty and Discrimination Indices of Technology Ability

Test (MT, B/W/T, E/E/T, GL/TD and SC.) Items

\begin{tabular}{|c|c|c|c|c|c|}
\hline & & \multicolumn{4}{|c|}{ DISCRIMINATION INDICES } \\
\hline & & $\begin{array}{c}\text { Negative } \\
\text { Unsuitable }-1.00 \text { to } \\
0.00 \\
\end{array}$ & $\begin{array}{c}\text { Low unsuitable } \\
0.00-0.24\end{array}$ & $\begin{array}{l}\text { High suitable } \\
+0.25-1.0\end{array}$ & Total \\
\hline \multirow{4}{*}{ 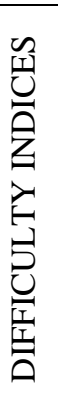 } & $\begin{array}{c}\text { High } \\
\text { unsuitable } \\
0.71-1.00\end{array}$ & 0 & 0 & 7 & 7 \\
\hline & $\begin{array}{l}\text { Moderate } \\
\text { suitable } \\
0.30-0.70\end{array}$ & 1 & 7 & 32 & 40 \\
\hline & $\begin{array}{c}\text { Low } \\
\text { unsuitable } \\
0.00 .-0.29\end{array}$ & 0 & 1 & 2 & 3 \\
\hline & Total & 1 & 8 & 41 & 50 \\
\hline
\end{tabular}

Table 2 indicates that out of the 50 items which made up TAT (MT, B/WT, E/ET, GL/TD and SC), 32 were found to have suitable difficulty and discrimination indices. Suggesting that, seven items as shown in the table, were very difficult, while eight items could not discriminate effectively. 2 items had suitable discrimination indices, but with low difficulty indices. Three items were found to be of low difficulty indices, meaning that they were very easy to be answered. The item difficulty index of technology ability test, ranged from $0.31-0.85$, and according to Nworgu, (2002), any level of difficulty of $0.30-0.70$ is ideal for an instrument. The discrimination index ranged from $0.25-1.00$. An ideal item is an instrument that has a discrimination index ranging from $0.30-1.00$ (Nworgu, 2002). After dropping faulty items, 41 items were finally assembled to form the final test items in the Technology Ability Test.

Research Question 2: What is the Reliability of the Technology Ability Test?

Kuder Richardson (K-R-20) approach was used to answer Research 2. The 41 items of the Technology Ability Test that survived item analysis were tested for Reliability, using K-R-20 Approach. 
Table 3: Reliability Test of TAT Using K-R 20 Approach

\begin{tabular}{|c|c|c|c|c|c|}
\hline ITEMS & $\begin{array}{l}\text { No of } \\
\text { PASS } \\
\end{array}$ & No of FAIL & PROP. OF PASS p & PROP. OF FAIL q & pq \\
\hline 1. & 58 & 62 & 0.48 & 0.52 & 0.25 \\
\hline 2. & 22 & 98 & 0.18 & 0.82 & 0.15 \\
\hline 3. & 33 & 87 & 0.28 & 0.73 & 0.20 \\
\hline 4. & 58 & 62 & 0.48 & 0.52 & 0.25 \\
\hline 5. & 48 & 72 & 0.40 & 0.60 & 0.24 \\
\hline 6 & 46 & 74 & 0.38 & 0.62 & 0.24 \\
\hline 7. & 47 & 73 & 0.39 & 0.61 & 0.24 \\
\hline 8. & 42 & 78 & 0.35 & 0.65 & 0.23 \\
\hline 9. & 35 & 85 & 0.29 & 0.73 & 0.21 \\
\hline 10. & 36 & 84 & 0.30 & 0.70 & 0.21 \\
\hline 11. & 59 & 61 & 0.49 & 0.51 & 0.25 \\
\hline 12. & 42 & 78 & 0.35 & 0.65 & 0.23 \\
\hline 13. & 70 & 50 & 0.58 & 0.52 & 0.23 \\
\hline 14. & 45 & 75 & 0.38 & 0.62 & 0.24 \\
\hline 15. & 57 & 63 & 0.48 & 0.52 & 0.25 \\
\hline 16. & 39 & 81 & 0.33 & 0.67 & 0.22 \\
\hline 17. & 59 & 61 & 0.49 & 0.51 & 0.25 \\
\hline 18. & 92 & 28 & 0.77 & 0.23 & 0.18 \\
\hline 19. & 24 & 96 & 0.20 & 0.80 & 0.16 \\
\hline 20. & 75 & 45 & 0.63 & 0.37 & 0.23 \\
\hline 21. & 75 & 45 & 0.63 & 0.37 & 0.23 \\
\hline 22. & 96 & 24 & 0.80 & 0.20 & 0.16 \\
\hline 23. & 47 & 73 & 0.39 & 0.61 & 0.24 \\
\hline 24. & 56 & 64 & 0.47 & 0.53 & 0.25 \\
\hline 25. & 63 & 57 & 0.53 & 0.47 & 0.25 \\
\hline 26. & 77 & 43 & 0.64 & 0.36 & 0.23 \\
\hline 27. & 42 & 78 & 0.35 & 0.65 & 0.23 \\
\hline 28. & 56 & 64 & 0.47 & 0.53 & 0.25 \\
\hline 29. & 47 & 73 & 0.39 & 0.61 & 0.24 \\
\hline 30. & 63 & 57 & 0.53 & 0.47 & 0.25 \\
\hline 31. & 82 & 38 & 0.68 & 0.32 & 022 \\
\hline 32. & 55 & 65 & 0.46 & 0.54 & 0.25 \\
\hline 33. & 72 & 48 & 0.60 & 0.40 & 0.24 \\
\hline 34. & 75 & 45 & 0.63 & 0.37 & 0.23 \\
\hline 35. & 92 & 28 & 0.77 & 0.23 & 0.18 \\
\hline 36. & 103 & 17 & 0.86 & 014 & 0.12 \\
\hline 37. & 69 & 51 & 0.58 & 0.42 & 0.24 \\
\hline 38. & 99 & 21 & 0.83 & 0.17 & 0.14 \\
\hline 39. & 53 & 67 & 0.44 & 0.56 & 0.25 \\
\hline 40. & 92 & 28 & 0.77 & 0.23 & 0.18 \\
\hline 41. & 101 & 19 & 0.84 & 0.16 & 0.13 \\
\hline
\end{tabular}

PROP. = Proportion

Descriptive statistics of TAT Score showed the following:

Mean $=50.425$

Standard Deviation $=11.963$ 
Therefore, applying the Kuder-Richardson K-R-20 formula, $\mathrm{K}-\mathrm{R}-20=\frac{\mathrm{K}}{\mathrm{K}-1}[1-\underline{\mathrm{Epq}}]$

Where $\mathrm{K}=$ No of items (i.e. 41), Epq $=8.97$ and $\mathrm{SD}=11.96$.

$$
\mathrm{K}-\mathrm{R} 20=\frac{41}{40} \frac{[1-8.97]}{11.96^{2}} \quad=\frac{(8.97)}{143.11}
$$

$$
\begin{aligned}
& \frac{41}{40}[1-0.063] \\
& =1.025 \times 0.94 \\
& =0.96
\end{aligned}
$$
was 0.96

Therefore, the reliability coefficient estimate of the final 41 test items

Researsh Question 3: What is the influence of gender on the performances of students in the Technology Ability Test?

The scores of male and female students on the Technology Ability Test (TAT) were separated and subjected to a simple descriptive procedure using mean and standard deviation. Summary of the test is presented in Table 4.

Table 4: Performances of Students in Different Subsets of the Technology Ability Test According to Gender

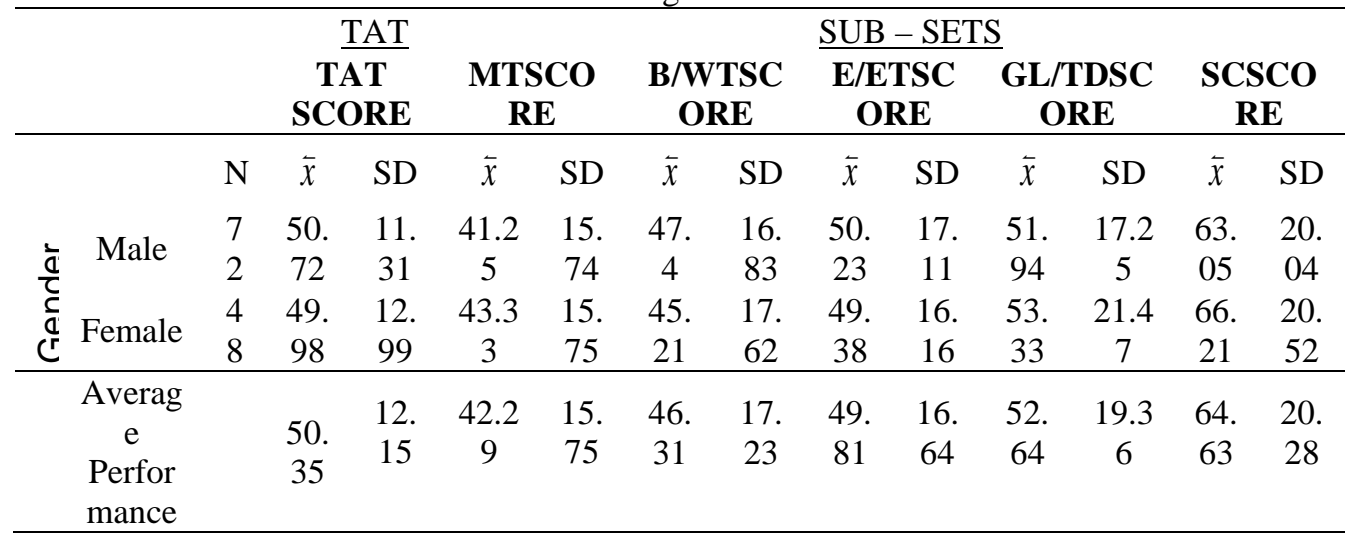

From the table, the overall mean score of males in TAT was 50.72 and Standard Deviation of 11.31, while the female students, the mean score was 49.98 with standard deviation of 12.99 . This revealed that the male students did slightly better than their female counterparts in the overall TATSCORE, but with higher standard deviation from the mean. For Mechanical Technology (MT), the mean score for male students was 41.25 with standard deviation of 15.74, while for female students, the mean score was 43.33 with stxndard deviation of 15.75 . This also revealed that the male students did slightly better than their female counterparts with almost the 
same standard deviation. In Building/Woodwork, the mean score for male students was 47.40 with standard deviation of 16.83; while the mean score for the female was 45.21 with standard deviation of 17.62. This mean score again indicated better performance of male students, while the female students had higher standard deviation of 17.62 against 16.83 for males. The male students also performed better than their female mates in Electrical/Electronics with mean score of 50.23(SD-17.10) against mean 49.38(SD-16.16) for females.

On the other hand, the female students performed better than their male counterparts in Graphic Language(TD) and Safety Consciousness. They had 53.33(SD-21.47), 66.21(SD-20.52) against 51.94(SD-17.23), 63.05(SD20.04) for the males respectively. In conclusion, the male students tended to perform better than female students in most of the subsets, but the female students exhibited greater homogeneity than their male counterparts in terms of measures of dispersion of scores from the mean scores

Research Question 4: What is the influence of university ownership on the performances of students in the Technology Ability Test? To answer this research question, results were summarised as shown in Table 5.

Table 5: Performances of Students in the Different Subsets of the Technology Ability Test According to University Ownership

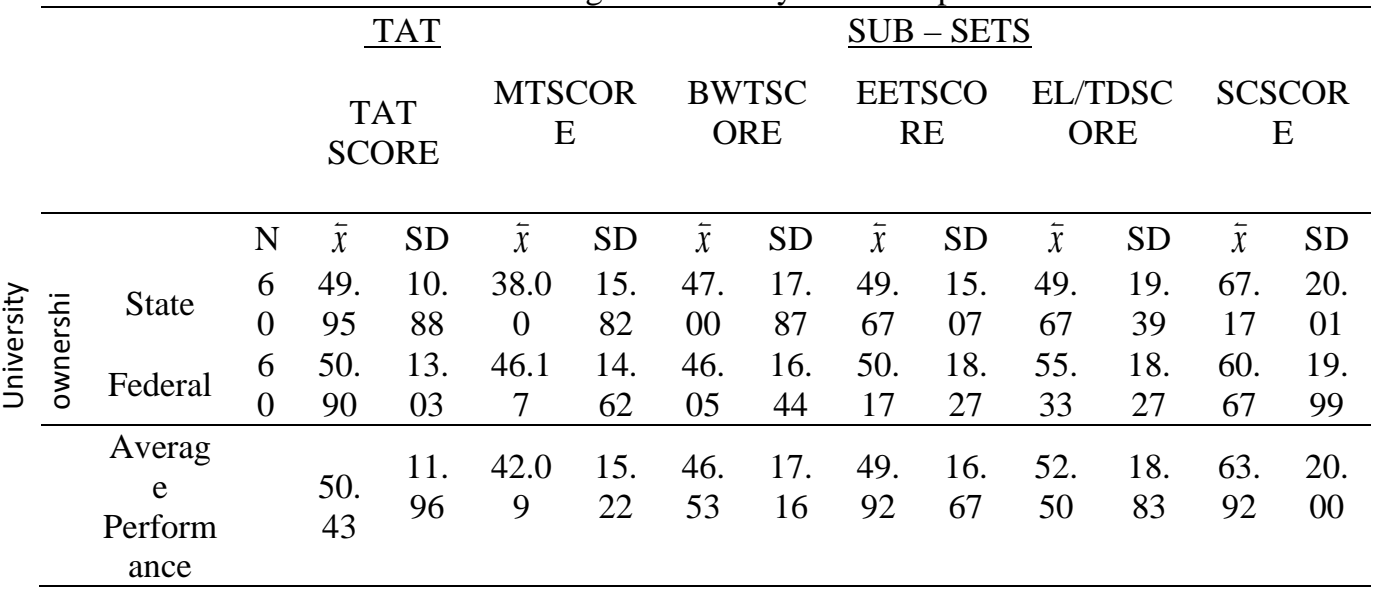

The data presented in Table 5 showed the mean and standard deviation of students' performance according to university ownership. Overall performance of students in the technology ability test revealed that students in the federal universities performed better with mean score of 50.90(SD13.03) against mean of 49.95(SD-10.88) for the state universities. Also, the performance of the federal universities was better in Mechanical, Electrical/Electronics technology and Graphic Language (TD) with 46.17(SD-14.62); 50.17(SD-18.27) and 55.33(18.27), as against 38.00(SD15.82); 49.67(SD-15.07) and 49.67(19.39) respectively. Regarding the 
performance of students in Building/Woodwork Technology and Safety Consciousness, the state universities performed better with mean score of 47.00(SD-17.87); 67.17(SD-20.01) as against 46.05(SD-16.44); 60.67(SD19.99) for the federal universities respectively.

Research question 5: What is the concurrent validity between the JAMB Scores and the TAT Scores?

Pearson product moment correlation statistics was used to answer this research question (see Table 6).

Table 6: Pearson Correlation between JAMB and TAT Scores $\mathrm{N}-120$

\begin{tabular}{|c|c|c|c|c|c|c|c|}
\hline & & $\begin{array}{c}\text { JAMB } \\
\text { (Scores) }\end{array}$ & JAMB & JAMB & JAMB & JAMB & JAMB \\
\hline $\begin{array}{l}\text { TAT } \\
\text { (Score) }\end{array}$ & $\begin{array}{c}\text { Pearson } \\
\text { Correl. } \\
\text { Sig. (2 tailed) }\end{array}$ & $\begin{array}{l}.012 \\
.893\end{array}$ & & & & & \\
\hline $\begin{array}{c}\text { MT } \\
\text { (Score) }\end{array}$ & $\begin{array}{l}\text { Pearson } \\
\text { Correl. Sig. } \\
\text { ( } 2 \text { tailed ) }\end{array}$ & & $\begin{array}{l}.139 \\
.129\end{array}$ & & & & \\
\hline $\begin{array}{l}\text { BW T } \\
\text { (Score) }\end{array}$ & $\begin{array}{c}\text { Pearson } \\
\text { Correl. } \\
\text { Sig. ( } 2 \text { tailed ) }\end{array}$ & & & $\begin{array}{l}.035 \\
.704\end{array}$ & & & \\
\hline $\begin{array}{c}\text { EET } \\
\text { (Score) }\end{array}$ & $\begin{array}{l}\text { Pearson } \\
\text { Correl. Sig. } \\
\text { (2 tailed) }\end{array}$ & & & & $\begin{array}{l}.119 \\
.194\end{array}$ & & \\
\hline $\begin{array}{l}\text { GL/TD } \\
\text { (Score) }\end{array}$ & $\begin{array}{l}\text { Pearson } \\
\text { Correl. Sig. } \\
\text { ( } 2 \text { tailed ) }\end{array}$ & & & & & $\begin{array}{l}.061 \\
.508\end{array}$ & \\
\hline $\begin{array}{c}\text { SC } \\
\text { (Score) }\end{array}$ & $\begin{array}{l}\text { Pearson } \\
\text { Correl. Sig. } \\
\text { ( } 2 \text { tailed ) }\end{array}$ & & & & & & $\begin{array}{l}.089 \\
.334\end{array}$ \\
\hline
\end{tabular}

Summary of the result in Table 6 shows that the Pearson correlation coefficient between TAT and JAMB is 0.012 . While that of the TAT Subsets MT, BWT, EET, GL/TD and SC is 0.139, 0.035, 0.119, 0.061 and 0.089 respectively. The conclusion is that TAT has negligible correlation with JAMB. Best and Kahn (2003) stated that Pearson correlation coefficient (r) of 0.00 to 0.20 is a negligible relationship, while coefficient of 0.80 to 1.00 is high to very high. The implication of this low correlation beteen the two tests, is that they are predicting different constructs.

\section{Hypotheses}

$\mathbf{H}_{\mathbf{0 1}}$ : There is no significant difference between the mean students'score of Federal and State universities on the Technology Ability Test. 
For this hypothesis, Scores of students were arranged across the 5 sub-sets (MT, BWT, EET, GL/TD and SC) and subjected to one-way analysis of variance (ANOVA) (see Table 7).

Table 7: ANOVA Using the Mean Squares, Sum of Squares and F-ratio for Federal and State Universities from TAT

\begin{tabular}{cccccc}
\hline $\begin{array}{c}\text { Source of } \\
\text { Variance }\end{array}$ & Df & Sum of Squares & Mean Squares. & F- Ratio & F- Crit. \\
\hline Btw Group & 3 & 119.958 & 39.986 & & \\
& & & & & \\
Within Group & 116 & 16911.367 & 145.788 & 0.274 & 2.68 \\
Total & 119 & 17031.325 & & & \\
\hline
\end{tabular}

From the Table 7 , F-calculated value is 0.274 , while F-critical value is 2.68 at 0.05 level of significance. It could be observed from the table that F-calculated is less than F-critical value table; therefore, the null hypothesis which states that "the mean scores of the students from different university ownership (Federal or State) in the Technology Ability Test (TAT) are not significant” is accept.

$\mathbf{H}_{\mathbf{0 2}}$ : There is no gender influence on the mean achievement scores of the students of both federal and state universities on the Technology Ability Test.

The scores of male and female students, on the Technology Ability Test (TAT) were separated and subjected to a t-test of difference between means of indept samples. Summary of the result is presented in Table 8.

Table 8: t-test of Significance of Difference in the Mean Scores of Males and Females on the Technology Ability Test

\begin{tabular}{|c|c|c|c|c|c|c|c|c|}
\hline Gender & Mean & SD & $\mathrm{N}$ & Df & $\begin{array}{c}\text { Std Error } \\
\text { Mean }\end{array}$ & $\mathrm{t}-\mathrm{Cal}$ & t-Crit. & Decision \\
\hline Male & 50.7222 & 11.31025 & 72 & 118 & & & & Uphold \\
\hline Female & 49.9792 & 12.99180 & 48 & & 1.6025 & 0.33 & 1.960 & $\mathrm{H}_{02}$ \\
\hline
\end{tabular}

As shown in Table 8, the t-calculated value is 0.33 , while the $t$ critical value at an alpha level of 0.05 is 1.960 . The decision rule is to reject the null hypothesis, if the calculated value exceeds the critical value at a given alpha level. The researcher therefore, upholds the null hypothesis and concludes that the influence of gender on the mean scores of the students on the Technology Ability Test is not significant.

\section{Summary of Findings}

In summary, results presented revealed that:

1. Technology Ability Test for the admission of candidates into technology education programmes has been developed. 
2. Forty of the TAT items had suitable and moderate difficulty indices, while forty one of the items were found to possess high and suitable discrimination indices. The item difficulty of TAT ranged from $0.31-0.85$, while the discrimination index ranged from $0.25-1.00$.

3. TAT was found to be valid and with a very high reliability coefficient of 0.96 .

4. The influence of gender on the mean achievement scores of students on the TAT is not significant.

5. The difference in the mean scores of the students from different university ownership is not significant.

6. TAT score correlated very lowly with JAMB score, showing that the two instruments are predicting different constructs.

\section{Discussion}

The discussion was organized under the following sub-sections:

i. $\quad$ Validity of Technology Ability Test (TAT).

ii. Reliability of TAT.

iii. Influence of gender on TAT.

Iv. Influence of university ownership on the mean scores of students on TAT.

iv. Relationship between TAT Score and JAMB Score.

\section{Validity of the TAT Items with Respect to Item Facility and Item Discrimination Capacity}

Experts that validated the instrument agreed that the test items possed good psychometric qualities. Results of TAT's psychometric qualities indicates that (40) $80 \%$ of the items possessed moderate (Suitable) difficulty and high (Suitable) discrimination indices. This proved the fact that the opinions of the experts who validated the TAT were adequately utilized. Based on the finding, it is observed that a good number of the TAT items possessed suitable psychometric qualities.

Content validation is basically concerned with the extent to which items of an instrument has achieved proper representation of the content from where the measuring test was drawn (Abonyi, 2003). This form of validation is mainly judgmental in that it is not easy to draw all samples of items from a vast content. This is clearly manifested when one considers that such vast content theoretically exist in most cases. They are either covered haphazardly or some areas not handled at all.

In the light of these, it is essential, therefore, to accept the fact that content validity can hardly be expressed as coefficient, but can be determined through a logical approach, that is determined by consensus. One way to ensure validity is to clearly streamline the goals to be implemented in 
a course of study and develop test items relating to that outline (Nunnally, 2001).

Uzoagulu (1994) rightly emphasized that these specification must show the content areas or topics to be covered, the instructional objectives or processes to be tested and the relative importance to individual topics on ensuring that the items were drawn in line with the emphases on the outline as determined by specialists. The items were further screened in relation to difficulty and discrimination analysis.

\section{Reliability of Technology Ability Test (TAT)}

Kuder Richardson (K-R 20) approach was used to answer research question 3. The reliability coefficient obtained from the test is 0.96 . This result is more than Uzoagulu (2011) recommendation that the reliability of a test instrument should not be less than 0.7. According to Anastasi (2006), if the reliability coefficient obtained from a test is 0.94 , this means that estimation resulting from true variance is 94 percent. While the remaining 0.6 percent is due to error variance. With a reliability coefficient of 0.96 , indicates that TAT is very reliable. With such a correlation, one would be confident that if a student achieves high in TAT, he is likely to perform well in technology education programme if offered admission

\section{Influence of Gender on the Technology Ability Test (TAT)}

The inflence of gender on the technology ability test was determined discriptively, statistically and inferentially. Summary of result in chapter four indicated slight influence discriptively. The mean TAT score for male students was 50.72 with standard deviation of 11.31, while for female students, the mean score was 49.98 with standard deviation of 12.99 . From the inferential perspective, summary of result showed the t-calculated value of 0.332, while the critical value at an alpha level of 0.05 is 1.658. The decision rule was to reject the null hypothesis if the calculated value exceeds the critical value at a given alpha level. The researcher concluded that influence of gender on the mean scores of the students on the technology ability test is not significant.

\section{Influence of University Ownership on the Mean Scores of Students on TAT}

Results of data analysis was summarized in chapter four. Summary of result indicated that the technology teacher education students of federal universities had a mean TAT score of 50.90 and standard deviation of 13.03, while their state universities counterparts had a mean TAT score of 49.95 and a standard deviation of 10.88 . This indicates a neglible (0.05) influence on the TAT. The result of the hypothesis showed that the calculation using 
ANOVA on federal and state university students' scores on TAT, Fcalculated was 0.274 , while F-table was 2.68 showing no significant difference, hence F-calculated is smaller than F-table. Based on this result, the researcher concluded that the influence of university ownership on technology ability test scores of students was not significant.

\section{Relationship between the TAT Scores and the JAMB Scores}

The scores of TAT and JAMB were correlated using Pearson product moment correlation co-efficient and the co-efficient was 0.012 According to Best and Kahn (2003), a Pearson correlation co-efficient (r) of 0.00 to 0.20 is a negligible relationship between two test scores, while a coefficient of 0.80 to 1.00 is high to very high. The implication of this is that, TAT has negligible correction with JAMB and the 2 test does not have concurrent validity.

This finding is not in line with Erickson and Wentling (1976) who stated that in tests correlation, those who score high on test A would be expected to score high on test B and those who scored low on test A would be expected to score low on test $B$ as well. To the extent that these expectations are realized, test $\mathrm{B}$ would be said to have concurrent validity with Test A. Erickson and Wentling (1976) concluded that the use of test B to replace test A would be justified. Technology Ability Test as a valid and reliable instrument was not developed to replace JAMB examination, but to be used as a screening test items after candidates must have sat and passed JAMB Examination.

\section{Conclusion}

The findings of this study demonstrated the plausibility of developing and validating a technology ability test for admission of students into technology education programmes. The ability test is usually a combination of achievement and aptitude tests. It measures the result of more general or broad innate qualities and learning experiences. With such test results from the ability test, the students' capability could be ascertained. The country will conserve many human and material resources when people with the necessary abilities are trained for the jobs they are best suited to do. When the ability to succeed in this programme is ascertained, then the lecturers will build upon this expectation. Students who showed poor safety consciousness could be enabled to improve on it when admitted.

\section{Educational Implications of the Study}

The findings of this study have a number of implications for both Technology Teacher Education and instrument development in general. In technology techer education, this study has developed an instrument that 
would be regularly used to admit capable students into technology teacher education programmes. Admiting capable candidates will improve the performances of such students when they are admitted into the programme.

To the teachers of technology courses, when achievement on technology courses is monitored, a guide on individual student's problem is provided. The implication is an improvement in the teaching and learning process in Nigerian universities.

In addition, admission officers and guidance counselors will objectively identify students with the capability to enter and succeed in technology courses in Nigerian universities. Such objective selection of students will minimize the huge financial loss the country incurs as a result of admitting the wrong people into technology education programmes.

Generally, the educational implication of this study is that, the quality of technology education in the country will improve, when capable students are admitted. While the individual students will be at their best during their study periods in the universities since their estimated ability suit the demands of the courses.

\section{Recommendations}

Based on the findings of this study, the researcher made the following recommendations:

1. Universities in Nigeria should be encouraged to use this technology ability test in admiting candidates into technology education programmes.

2. Seminars and workshops should be organised for admission officers to enlighten them on the use of this newly developed instrument.

3. Researchers interested in technology ability, should be encouraged to use this new instrument.

\section{References:}

Abonyi, S.O. (2003). Instrumentation in behavioural research: A practical Approach. Enugu: Fulladu Publishing Company.

Agwagwa, U. A., and Agbaegbu, C. O. (2007). The relevance of JAMB in Nigeria's admission. Journal of Curriculum Studies, 4(2), 11-13.

Akinyemi, G. O. (2007). Effective evaluation of science: Impediments and implications for science teachers. In O.O. Busari (Ed.), 40 ${ }^{\text {th }}$ Annual Conference Proceeding of Science Teachers Association of Nigeria (STAN), 67-70.

Anene, G.U., and Ndubisi, O.G. (2007). Test development process.In B.G. Nworgu (Ed.), Educational measurement and evaluation: Theory and practice. Nsukka: Hallmark publishers.

Anastasi, A. C. (2006). The use of Psychological testing. Lagos: Nobert Press. 
Ayo, C.K. (2012). The prospects of e-examination implementation in Nigeria. Turkish Journal of Distance Education, 8(4), 23-29.

Best, J. W., and Kahn, J. V. (2003). Research in education. Delhi: Rahul Print O. Pack Inc.

Erickson, R.C., and Wentling, T.T. (1976). Measuring students'growth. Boston: Allyn and Bacon Inc.

Ezeudu, M. A., and Umoh, C. F. (2007). The role of admission officers in the process of admission of candidates into the universities. Journal of Educational Foundations, 4(1), 32-37.

Garba, N.L. (1993). Development of an instrument for evaluating practical projects in wood working. Unpublished PhD Thesis, University of Nigeria, Nsukka.

Ikeotuonye, A.I. (2011). The reliability and construct validity of the differencial aptitude tests in Kaduna State. Benue State University Jounal of Education, 1(1), 13-20.

Imah, I., and Nneji, N.G. (2006). Wastage in technical teacher production: causes and remedies. Jounal of Nigerian Associationof Teachers of Technology, 5(2), 3-10.

Modili, A.A. (2005). The relationship between students' vocational aspirations and their courses of study in technical colleges in Kwara State. Unpublished M.Ed. Dessertation, Federal University of Technology, Mina.

Nunnally, J.C. (2011). Psychometric theory. New Delhi: Tata McGraw-Hill Publishing Company Ltd.

Nwafor, E. C., and Onuoha, B.A. (2014). Analysis of factors responsible for examination malpractices in Nigeria. In Onyeyinka, E.B. (Ed.), Education in contemporary Nigeria. Ibadan: Oladipo Press Ltd.

Nwana, O.C. (2001). Educational measurement for teachers. Lagos: Thomas Nelson Ltd.

Nworgu, B.G. (2002). Educational measurement and evaluation: Theory and practice. Nsukka: Hallman Publishers.

Obi, C.I. (2005). Competency based education: The alternative for effective in-service technology teacher education in Nigeria. Journal of Nigerian Education, 5(2), 89-95.

Ohize, E.J. (2007). Repositioning technology education for Nigeria's industrial growth through effective funding. A Paper Presented at the $20^{\text {th }}$ Annual Conference of the Nigerian Association of Teachers of Technology held at Kaduna Polytechnic $5^{\text {th }}$ to $9^{\text {th }}$ November.

Okoro, O. M. (2006). Measurement and evaluation in education. Obosi: Pacific Publishers LTD.

Olaitan, S.O. (2006). Vocational and technical education in Nigeria: Issues and analysis. Onitsha: Noble Graphic Publishers. 
Salami, K. A. (2007). Technology teacher training for development in Nigeria: problems and remedies. A paper Presented at the $20^{\text {th }}$ Annual Conference of the Nigerian Association of Teachers of Technology. (NATT) Kaduna $5^{\text {th }}-9^{\text {th }}$ November.

Udenze, D.E. (2006). Imperatives for successful vocational teacher education in Nigeria: Imperatives for national development. Journal of Nigerian Association of Teachers of Technology (JONATT), 6(2), 23-32.

Udigwe, U.A. (2000). The needs for middle level technological manpower in industrial education in Anambra State. Unpublished MEd Dessertation, University of Benin, Benin.

Ugwu, E. B. (2006). Process errors committed by students in providing some geometric theorems. Unpublished MEd Dessertaion, University of Nigeria, Nsukka.

Umeh, E. (2002). The role of trained technicians in the technological development of Nigeria. A Paper Presented at the graduation ceremony of the Government Technical College, Enugu. July, 8.

Umo, M. E. (2006). Constraints to quality technical education in Nigeria, Technology Education Research Journal, 1(4), 22-31.

Uzoagulu, A. E. (1994). Development and standardization of introduction technology achievement test for junior secondary schools. Unpublished $\mathrm{PhD}$ Thesis, University of Nigeria, Nsukka.

Uzoagulu, A. E. (2011). Practical guide to writing research project reports in tertiary institutions. Enugu: John Jacobs Classic Publishers Ltd.

Yaduma, C. A. (2006). An instrument for aptitude evaluation for national development. Paper presented at the international conference on educational research. University of Calabar, Calabar $16^{\text {th }}$ July. 